RESIDENT

\& FELLOW

SECTION

Section Editor

Mitchell S.V. Elkind,

MD, MS

N. Montano, MD

F. Signorelli, MD

T. Tufo, MD

S. Sioletic, MD

L. Lauretti, MD

R. Pallini, MD

G. Maira, MD

F. Doglietto, MD

Address correspondence and reprint requests to Dr. Nicola Montano, Institute of

Neurosurgery, Catholic

University, Largo Agostino

Gemelli, 8, 00168 Rome, Italy nicolamontanomd@yahoo.it

\title{
Teaching NeuroImages: Extralesional bleeding of conus medullaris cavernoma
}

\section{Figure 1 \\ Spinal MRI}
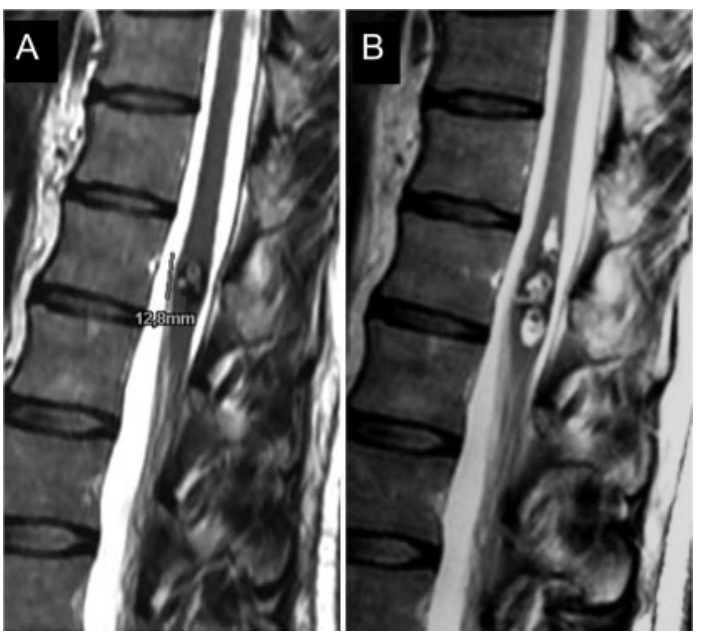

Sagittal T2-weighted image showing the conus medullaris cavernoma at time of diagnosis (A); 3 months later (B), extralesional bleeding was evident.

A 42-year-old man with a 9-month history of right leg paresthesias was admitted because of the acute onset of numbness and weakness of the left leg with gait impairment. Neurologic examination demonstrated bilateral lower limb hyporeflexia. MRI showed acute extralesional bleeding of a conus medullaris cavernoma, which had been discovered 3 months before (figure 1, A and B). Surgical removal was performed (figure 2). At 3 months follow-up, the patient had mild lower limb paresthesias; leg weakness had resolved.

\section{Figure 2 Histopathology}

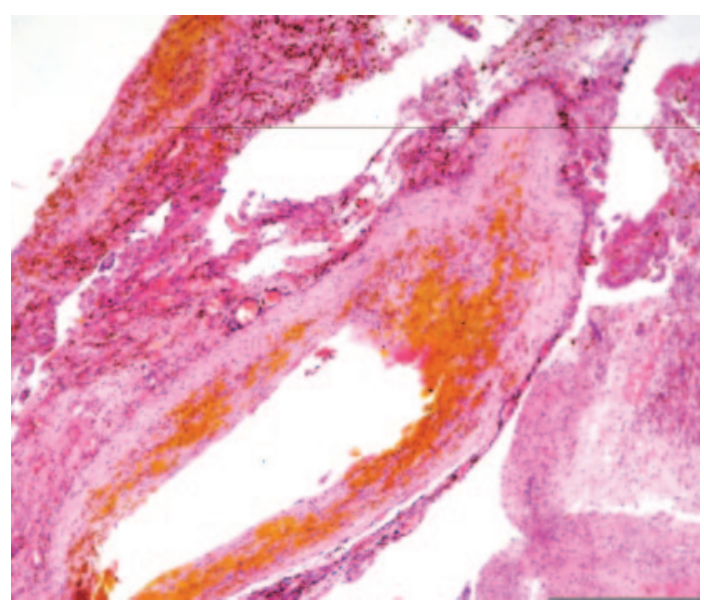

Hematoxylin \& eosin staining (magnification $\times 100$ ) showing a large vessel and irregular tissue spaces with cystically enlarged lumina and thin walls filled with hemosiderin pigment, typical features of cavernous hemangioma.

The conus medullaris is a rare location for a cavernous hemangioma. ${ }^{1}$ Surgery may be performed in cases with acute, symptomatic hemorrhage, although the benefits remain uncertain. ${ }^{1,2}$

\section{REFERENCES}

1. Zevgaridis D, Medele RJ, Hamburger C, Steiger H-J, Reulen H-J. Cavernous haemangiomas of the spinal cord: a review of 117 cases. Acta Neurochir 1999;141:237-245.

2. Kharkar S, Shuck J, Conway J, Rigamonti D. The natural history of conservatively managed symptomatic intramedullary spinal cord cavernomas. Neurosurgery 2007;60:865-872. 


\section{Neurology}

Teaching NeuroImages: Extralesional bleeding of conus medullaris cavernoma N. Montano, F. Signorelli, T. Tufo, et al. Neurology 2010;75; 1

DOI 10.1212/WNL.0b013e3181e6209b

This information is current as of July 5, 2010

Updated Information \& Services

References

Subspecialty Collections

Permissions \& Licensing

Reprints including high resolution figures, can be found at: http://n.neurology.org/content/75/1/e1.full

This article cites 2 articles, 0 of which you can access for free at: http://n.neurology.org/content/75/1/e1.full\#ref-list-1

This article, along with others on similar topics, appears in the following collection(s):

All Spinal Cord

http://n.neurology.org/cgi/collection/all_spinal_cord Arteriovenous malformation

http://n.neurology.org/cgi/collection/arteriovenous_malformation Clinical neurology history

http://n.neurology.org/cgi/collection/clinical_neurology_history

MRI

http://n.neurology.org/cgi/collection/mri

Information about reproducing this article in parts (figures,tables) or in its entirety can be found online at:

http://www.neurology.org/about/about_the_journal\#permissions

Information about ordering reprints can be found online:

http://n.neurology.org/subscribers/advertise

Neurology ${ }^{\circledR}$ is the official journal of the American Academy of Neurology. Published continuously since 1951, it is now a weekly with 48 issues per year. Copyright . All rights reserved. Print ISSN: 0028-3878. Online ISSN: 1526-632X.

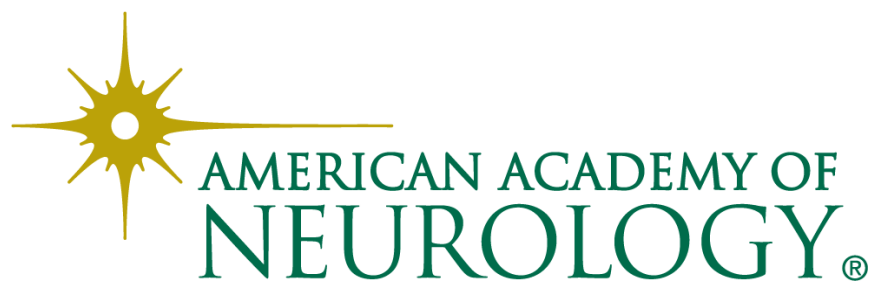

